\title{
Regulation of the Photon Spectrum on Growth and Nutritional Attributes of Baby-Leaf Lettuce at Harvest and during Postharvest Storage
}

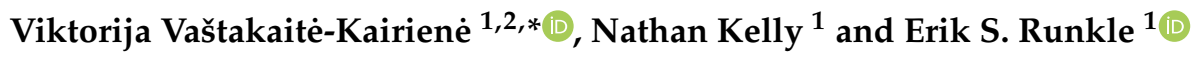 \\ 1 Department of Horticulture, Michigan State University, 1066 Bogue Street, East Lansing, MI 48824-1325, USA; \\ kellyna5@msu.edu (N.K.); runkleer@msu.edu (E.S.R.) \\ 2 Lithuanian Research Centre for Agriculture and Forestry, Institute of Horticulture, Kaunas Street 30, \\ LT-54333 Babtai, Lithuania \\ * Correspondence: viktorija.vastakaite-kairiene@lammc.lt
}

Citation: Vaštakaitė-Kairienè, V.; Kelly, N.; Runkle, E.S. Regulation of the Photon Spectrum on Growth and Nutritional Attributes of Baby-Leaf Lettuce at Harvest and during Postharvest Storage. Plants 2021, 10, 549. https://doi.org/10.3390/plants 10030549

Received: 22 February 2021

Accepted: 11 March 2021

Published: 14 March 2021

Publisher's Note: MDPI stays neutral with regard to jurisdictional claims in published maps and institutional affiliations.

Copyright: (c) 2021 by the authors. Licensee MDPI, Basel, Switzerland. This article is an open access article distributed under the terms and conditions of the Creative Commons Attribution (CC BY) license (https:// creativecommons.org/licenses/by/ $4.0 /)$.

\begin{abstract}
The photon flux density (PFD) and spectrum regulate the growth, quality attributes, and postharvest physiology of leafy vegetables grown indoors. However, limited information is available on how a photon spectrum enriched with a broad range of different wavebands regulates these factors. To determine this, we grew baby-leaf lettuce 'Rouxai' under a PFD of $200 \mu \mathrm{mol} \mathrm{m}^{-2} \mathrm{~s}^{-1}$ provided by warm-white (WW; control) light-emitting diodes (LEDs) supplemented with either $30 \mu \mathrm{mol} \mathrm{m} \mathrm{m}^{-2} \mathrm{~s}^{-1}$ of ultraviolet-A (+UV30) or $50 \mu \mathrm{mol} \mathrm{m}^{-2} \mathrm{~s}^{-1}$ of blue (+B50), green (+G50), red (+R50), or WW (+WW50) light. We then quantified growth attributes and accumulated secondary metabolites at harvest and during storage in darkness at $5{ }^{\circ} \mathrm{C}$. Additional $+\mathrm{G} 50$ light increased shoot fresh and dry weight by 53\% and 59\% compared to the control. Relative chlorophyll concentration increased under $+\mathrm{UV} 30,+\mathrm{G} 50$, and especially $+\mathrm{B} 50$. At harvest, $+\mathrm{B} 50$ increased total phenolic content (TPC) by $25 \%$ and anthocyanin content (TAC) by 2.0 -fold. Additionally, +G50 increased antiradical activity (DPPH) by $29 \%$. After each day of storage, TPC decreased by 2.9 to $7.1 \%$ and DPPH by 3.0 to $6.2 \%$, while TAC degradation was less pronounced. Principal component analysis indicated a distinct effect of $+\mathrm{G} 50$ on the lettuce at harvest. However, concentrations of metabolites before and during storage were usually greatest under the $+\mathrm{B} 50$ and $+\mathrm{R} 50$ treatments.
\end{abstract}

Keywords: anthocyanins; DPPH; light-emitting diodes; phenols; white light

\section{Introduction}

Controlled-environment agriculture (CEA) enables growers to control environmental and cultural factors, thus extending the growing season and achieving a more uniform crop. CEA encompasses semi- or fully-closed growing structures such as greenhouses or indoor farms (i.e., plant factories) [1]. The typical features of indoor farms are the efficient use of water and fertilizer, automatic air temperature and humidity control, and electric lighting, which enable year-round crop production on a demand basis [2]. The photon flux density (PFD) and spectrum are two of the main environmental factors that influence plant productivity and quality when crops are produced indoors. Solid-state light-emitting diodes (LEDs) have become increasingly popular because of their efficient conversion of electrical energy to light energy for indoor plant cultivation [3]. Moreover, LEDs have many advantages over fluorescent or high-intensity discharge lights such as a longer lifetime, smaller size, and faster switching. Finally, narrow-band LEDs are highly adjustable, allowing growers to regulate photosynthesis, plant morphology, and metabolism at any growth stage [4]. The need to deliver an efficient PFD and spectrum that balances crop development, growth, and quality attributes, while considering energy consumption, necessitates further research on photomorphogenesis and LED technology [5].

Lettuce (Lactuca sativa) is one of the most widely produced and consumed leafy greens in CEA because it is easy to prepare, is affordable, and has numerous nutritional 
benefits [6,7]. Although lettuce has high water content and is low in calories, it enriches the human diet with dietary fiber and important mineral nutrients, such as $\mathrm{K}, \mathrm{Fe}$, and $\mathrm{Na}$; vitamins $\mathrm{B}_{9}$ (folate), $\mathrm{C}$, and $\mathrm{E}$; polyunsaturated fatty acids; and bioactive compounds such as carotenoids and polyphenols that have antioxidant properties [7]. The consumption of nutrient-rich vegetable products can significantly counter human health problems like obesity and chronic disorders, including diabetes or cardiovascular disease [8,9].

Previously published studies revealed that physiological responses of lettuce are strongly influenced by environmental conditions. Lettuce is a common model plant for photophysiological studies in CEA because of its economic importance, short production cycle, and sensitivity to the photon spectrum. For example, supplementing cool-white fluorescent lamps with blue $(B ; 400-500 \mathrm{~nm}$, peak $=476 \mathrm{~nm})$ and ultraviolet-A (UV-A; $315-400 \mathrm{~nm}$, peak $=373 \mathrm{~nm}$ ) LEDs increased anthocyanin content by $11 \%$ and $31 \%$, B LEDs increased carotenoid concentration by $12 \%$, and red $(R ; 600-700 \mathrm{~nm}$, peak $=658 \mathrm{~nm})$ LEDs increased phenolic content by $6 \%$ in 'Red Cross' baby-leaf lettuce [10]. Additionally, supplemental far-red (FR; 700-800 nm; peak $=734 \mathrm{~nm}$ ) LEDs increased growth and morphological indices from 14 to $28 \%$; however, the phytochemical contents in plants decreased from 11 to $40 \%$.

More recently, studies have shown that increasing the percentage of $B($ peak $=449 \mathrm{~nm}$ ) light decreased the fresh and dry mass of red-leaf lettuce, for example in 'Rouxai' by up to $63 \%$ and $54 \%$, respectively [11]. The same study reported that green $(G ; 500-600 \mathrm{~nm}$, peak $=526 \mathrm{~nm}$ ) light had negligible effects on morphology, foliage coloration, essential nutrients, or sensory attributes, regardless of the B PFD. However, increasing the B PFD increased red foliage coloration and the concentrations of several macronutrients (e.g., nitrogen and magnesium) and micronutrients (e.g., zinc and copper). In another lettuce study, the addition of $\mathrm{G}($ peak $=510 \mathrm{~nm})$, yellow $(Y$; peak $=595 \mathrm{~nm})$, or orange $(\mathrm{O}$; peak $=622 \mathrm{~nm})$ light to $\mathrm{R}$ (peaks $=627$ and $660 \mathrm{~nm}$ ), B (peak $=455 \mathrm{~nm}$ ), and FR (peak $=735 \mathrm{~nm}$ ) light did not have a pronounced effect on red-leaf lettuce 'Red Cos' or green-leaf lettuce 'Lobjoits

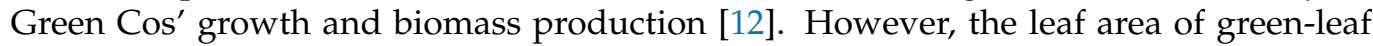
lettuce increased by $30 \%$, and fresh weight (FW) increased by $22 \%$, under supplemental UV-A (peak $=380 \mathrm{~nm}$ ) light. Additionally, supplemental UV-A increased the nitrite content of green-leaf lettuce (by 6.4 times). In red-leaf lettuce, UV-A slightly reduced the nitrite content, but increased the nitrate content in leaves by $62 \%$ compared to light provided by R + B + FR LEDs, while supplemental G and O light decreased nitrate content by $47 \%$ and 58\% respectively. Supplemental UV-A, G, Y, and O light had inconsistent and often contrasting effects on additional nutrients, including free amino acids, sucrose, fructose, maltose, oxalic acid, citric acid, and malic acid [12].

Baby-leaf greens have become increasingly popular for consumers as a ready-toeat salad of immature leaves with attractive colors and shapes, and appealing tastes. Cultivation conditions and plant age at harvest are factors that affect the quality attributes of leafy greens [13]. Plants harvested at the early development stage with meager storage reserves and high metabolic rate (e.g., baby-leaf greens) might deteriorate more rapidly, while more mature plants with high storage reserves and low metabolic rate might have a longer shelf life [14]. Few studies have been published on the effects of pre-harvest lighting on biochemical compounds in greens during postharvest storage. Pre-harvest $\mathrm{R}$ light (peak $=660 \mathrm{~nm}, 80 \mu \mathrm{mol} \mathrm{m}{ }^{-2} \mathrm{~s}^{-1}$ ) for $24 \mathrm{~h}$ before harvest notably delayed the degradation of aliphatic, indole, and total glucosinolates in Chinese kale (Brassica oleracea var. alboglabra 'Bailey') sprouts during postharvest storage, compared to those grown under white (W) light. Additionally, vitamin C was remarkably higher in plants treated with $\mathrm{R}$ light on the first and second day after harvest [15]. In another study, pre-harvest lighting with $\mathrm{R}+\mathrm{W}$ light or monochromatic B light decreased the nitrate content in lettuce 'Lollo Bionda' [16]. In the same study, the nitrate content in wild rocket (Diplotaxis tenuifolia) decreased following pre-harvest lighting from $\mathrm{R}+\mathrm{W}, \mathrm{R}+\mathrm{B}$, and $\mathrm{R}+\mathrm{W}+\mathrm{FR}$ light.

The effect of pre-harvest LED lighting on the nutritional quality of leafy greens at harvest, and especially during postharvest storage, remains unclear. Further investigations 
are needed to determine whether a photon spectrum for leafy greens production indoors can maximize their nutritive value at harvest and during storage. The bewildering array of choices, complications, and interactions caused by using different narrow-bandwidth LEDs for indoor crop production encourages research on plant responses to W LEDs, which, depending on amounts and proportions of particular phosphors, emit B, G, R, and, to a small extent, FR light [5]. We grew baby-leaf 'Rouxai' lettuce under warm-white (WW) LEDs or with supplemental UV-A, B, G, R, or WW light to determine the effects of supplemental lighting on growth, morphological indices, accumulation of secondary metabolites, and antioxidant activity at harvest and during short-term storage in darkness at $5{ }^{\circ} \mathrm{C}$. We postulated that supplemental lighting treatments of UV-A or B would increase the nutritional traits at harvest and after postharvest storage, while additional G, R, or FR would increase growth but have little, no, or negative effects on nutritional content.

\section{Results}

\subsection{Shoot Weight and Plant Morphology}

On harvest day, shoot FW of baby-leaf 'Rouxai' lettuce was the highest under the $+\mathrm{G} 50$ treatment $\left[200 \mu \mathrm{mol} \mathrm{m}{ }^{-2} \mathrm{~s}^{-1}\right.$ of WW supplemented with $50 \mu \mathrm{mol} \mathrm{m} \mathrm{m}^{-2} \mathrm{~s}^{-1}$ of green (G) light] (Figure 1A). The +G50 treatment significantly increased shoot FW by 53\% compared to the control (WW). Compared with the control, there was no significant effect on shoot FW when plants were grown under the +UV30, +WW50, +B50, and + R50 treatments $\left(200 \mu \mathrm{mol} \mathrm{m}{ }^{-2} \mathrm{~s}^{-1}\right.$ of WW supplemented with $30 \mu \mathrm{mol} \mathrm{m} \mathrm{m}^{-2} \mathrm{~s}^{-1}$ of UV-A, or with $50 \mu \mathrm{mol} \mathrm{m} \mathrm{m}^{-2} \mathrm{~s}^{-1}$ of WW, blue (B), and red (R) light, respectively). Similarly, plants grown under the +G50 treatment had increased shoot dry weight (DW) by 59\%, and there were no significant differences between other lighting treatments on shoot DW compared to the control (Figure 1B). Finally, the leaf length of baby-leaf lettuce under the control was similar to those under the +WW50, +UV30, +B50, +G50, and +R50 lighting treatments (Figure 1C). However, the +WW50 and +G50 treatments expanded leaf width by $17 \%$ and $20 \%$, respectively, compared to the control (Figure 1D).
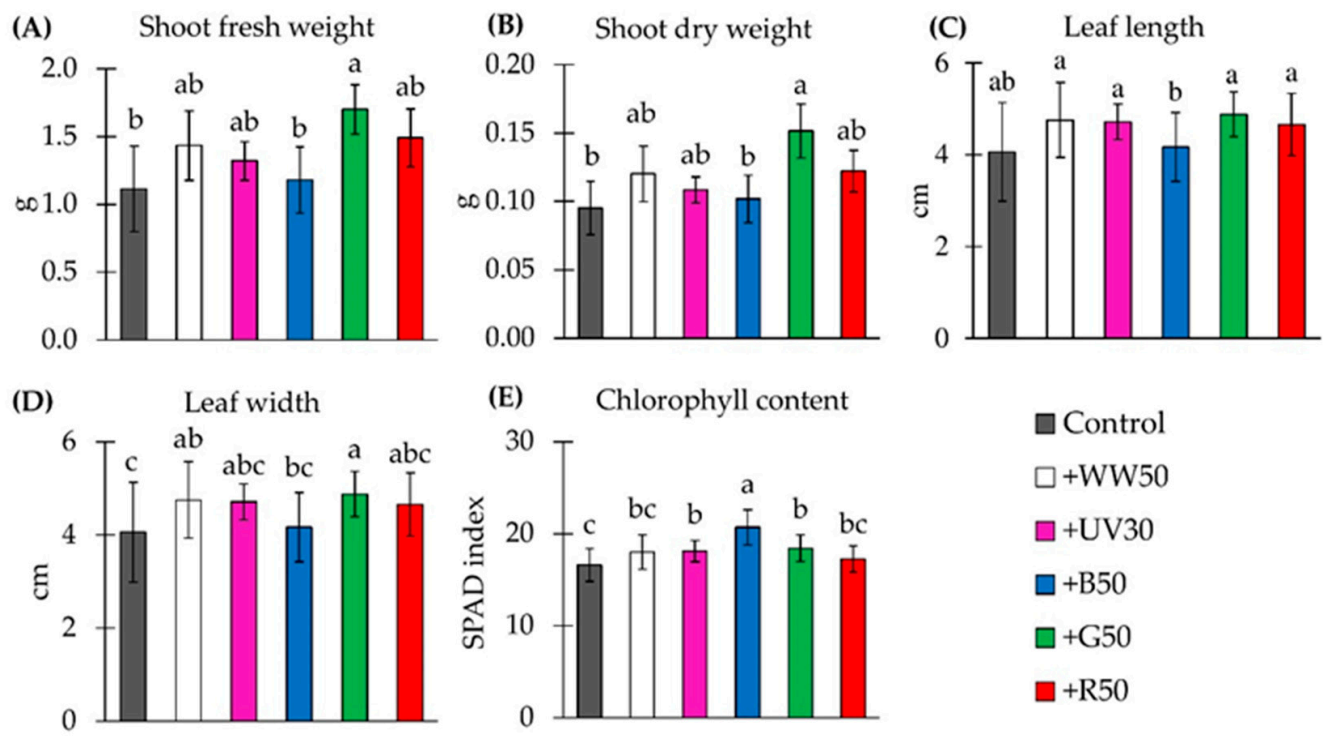

Figure 1. Growth and morphological parameters and chlorophyll content of 'Rouxai' baby-leaf lettuce on harvest day. Plants were grown under six lighting treatments at a photon flux density of $200 \mu \mathrm{mol} \mathrm{m}{ }^{-2} \mathrm{~s}^{-1}$ from warm-white (WW; peak $=639 \mathrm{~nm})$ LEDs (control treatment) without or with an additional $30 \mu \mathrm{mol} \mathrm{m}^{-2} \mathrm{~s}^{-1}$ of UV-A (peak $\left.=385 \mathrm{~nm}\right)(+\mathrm{UV} 30)$ or $50 \mu \mathrm{mol} \mathrm{m}{ }^{-2} \mathrm{~s}^{-1}$ of $\mathrm{WW}$, blue $(B$; peak $=449 \mathrm{~nm})$, green $(\mathrm{G}$; peak $=526 \mathrm{~nm})$ or red $(\mathrm{R}$; peak $=664 \mathrm{~nm})(+\mathrm{WW} 50,+\mathrm{B} 50$, + G50, and +R50, respectively) light. For shoot fresh weight (A), shoot dry weight (B), leaf length (C), leaf width (D), and chlorophyll content $(\mathrm{E})$, data are means \pm standard deviation (SD) of two replications with 10 samples per replication $(n=20)$. The third leaf was measured for leaf length and width $(\mathbf{C}, \mathbf{D})$. Means with different letters are significantly different from control treatment at the $\alpha=0.05$ level by Tukey's honestly significant difference test. 


\subsection{Chlorophyll Concentration}

Non-destructive SPAD index measurements showed an increase in relative chlorophyll content in baby-leaf lettuce grown under +UV30 (by 9\%), +B50 (by 25\%), and +G50 treatments (by $11 \%$ ) compared to the control (Figure 1E). The SPAD index of plants grown under + WW50 and + R50 treatments was similar to plants grown under the control treatment.

\subsection{Total Phenolic Content}

There were no significant differences in total phenolic content (TPC) in baby-leaf lettuce under the lighting treatments at harvest, except for plants grown under the $+\mathrm{B} 50$ treatment, where TPC significantly increased by $25 \%$ compared to the control (Table S2). The application of any supplemental lighting treatment decreased the rate at which TPC decreased during postharvest storage. For instance, TPC of control plants decreased by $7.1 \%$ per day of postharvest, but only by $5.5 \%$ or $5.4 \%$ when $50 \mu \mathrm{mol} \mathrm{m} \mathrm{m}^{-2} \mathrm{~s}^{-1}$ of WW (+WW50) or B (+B50) light was added to the control (Figure 2A, Table S2). Finally, + R50 led to the greatest preservation of TPC, with a rate of decrease of only $2.9 \%$ per day, resulting in the highest TPC at the end of storage.

\subsection{Total Anthocyanin Content}

Similar to TPC, the greatest total anthocyanin content (TAC) in 'Rouxai' baby-leaf lettuce on harvest day was in plants grown under the +B50 treatment, which was about 2.0-fold higher than plants grown under the control treatment (Table S1). Furthermore, the $+\mathrm{B} 50$ treatment led to 26 to $38 \%$ higher TAC than in the other supplemental lighting treatments. However, while $+\mathrm{B} 50$ was the most effective at increasing TAC at harvest, it was not necessarily the most effective at preserving TAC during postharvest storage (Figure 2B, Table S2); it decreased by $4.9 \%$ per day, which was similar to or less than the $5.7 \%$ decrease per day that occurred when plants were grown under the control treatment but more than other supplemental lighting treatments. TAC in plants grown under $+\mathrm{WW} 50,+\mathrm{UV} 30$, and $+\mathrm{G} 50$, decreased at an average daily rate of $2.3 \%, 3.8 \%$, and $1.5 \%$, respectively, and did not decrease when grown under the $+\mathrm{R} 50$ treatment. Finally, $+\mathrm{R} 50$ and $+\mathrm{B} 50$ provided to the plants during the growing period led to some of the highest TACs by the end of storage, while for the control, it led to the lowest concentrations.

\subsection{DPPH Free Radical Scavenging Activity}

On harvest day, lettuce grown under +G50 had 29\% greater 2.2-Diphenyl-1-picrylhydrazyl free radical scavenging activity (DPPH) compared to the control (Table S1). However, supplemental UV-A (+UV30), or additional WW, B, and R (+W50, +B50, +R50, respectively) light did not significantly increase DPPH activity compared to the control treatment. Although supplemental G light was the most effective at increasing DPPH free radical scavenging activity at harvest, lettuce plants grown under $+\mathrm{R} 50$ had among the lowest rates of decrease in DPPH activity during $7 \mathrm{~d}$ of postharvest storage (Figure 2C, Table S2). Those plants decreased in DPPH activity by $3.0 \%$ per day of storage, while control plants and those grown under the $+\mathrm{B} 50,+\mathrm{G} 50$, and $+\mathrm{WW} 50$ decreased at a daily rate of $4.1 \%$ to $4.5 \%$. Leaves from plants grown under the $+\mathrm{UV} 30$ treatment had the sharpest decline in DPPH activity at $6.2 \%$ per day of storage. Finally, the + R50 treatment led to the greatest preservation of DPPH activity by the end of storage, while +UV30 led to the lowest. 


\section{Control $\cdot 0 \cdot+\mathrm{WW} 50 \rightarrow+\mathrm{UV} 30 \rightarrow+\mathrm{B} 50-\mathrm{G}+\mathrm{G} 50-\mathrm{w}-\mathrm{R} 50$}

(A) Total phenolic content

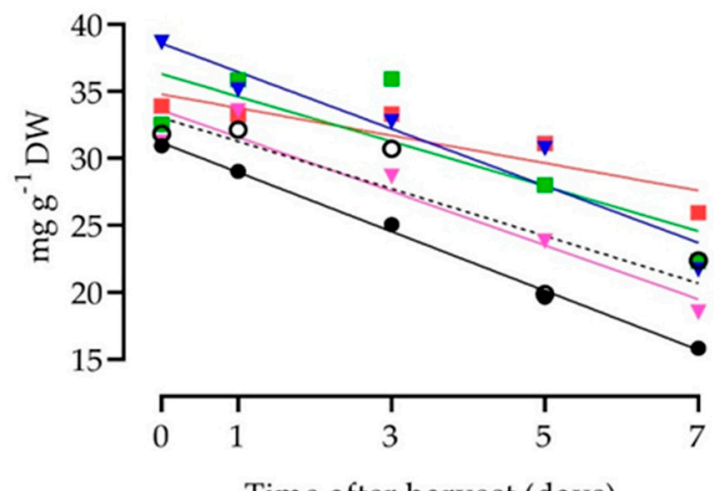

Time after harvest (days)

(B) Total anthocyanin content

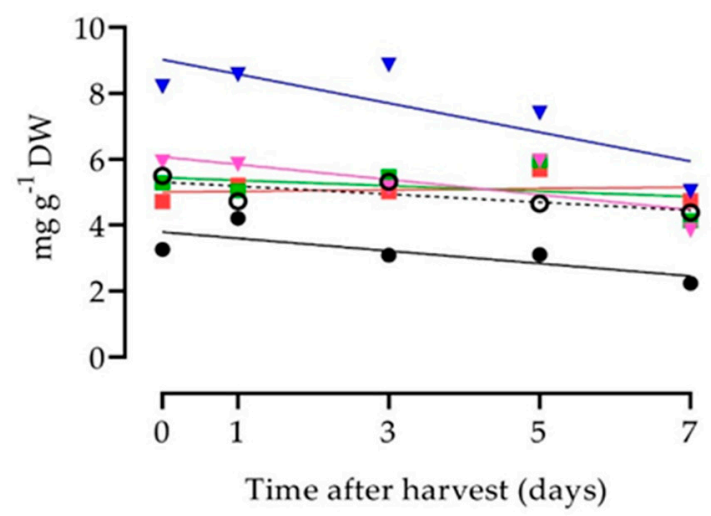

(C) DPPH free radical scavening activity

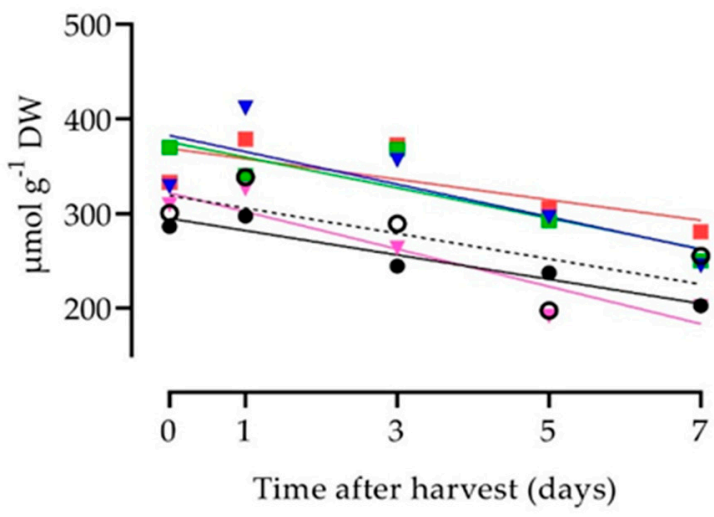

Figure 2. Concentrations of total phenolic content (A), total anthocyanin content (B), and DPPH free radical scavenging activity $(\mathbf{C})$ in 'Rouxai' baby-leaf lettuce from harvest until $7 \mathrm{~d}$ after harvest. See Table 2 for a description of treatments. Data are presented as the mean of two replications with three randomly selected plants and three analytical measurements per sample $(n=6)$. Linear regression was performed for each treatment and compound. 


\subsection{Principal Component Analysis}

The principal component analysis (PCA) biplot (Figure 3) presents the effects of the six lighting treatments on plant growth, morphological and biochemical parameters, as well as the relationships between FW, DW, leaf length, leaf width, relative chlorophyll content, DPPH, TPC, and TAC in 'Rouxai' baby-leaf lettuce on harvest day. The screen plots (Figure S1) of the PCA showed that the first two eigenvalues accounted for most of the variance in the dataset. The PCA factor loadings, scores, and eigenvalues for the first two principal components (F1 and F2) are presented in Table 1. In a PCA biplot, two vectors with an angle $<90^{\circ}$ show a positive correlation, and two vectors with an angle $>90^{\circ}$ have a negative correlation. The first two PCAs extracted from the components amounted to $70.72 \%$ of the total data variance.

Table 1. Factor loadings, eigenvalues, variability (\%), cumulative variability (\%), and scores for the first two principal (F1-F2) components for growth, morphological, and biochemical measurements of 'Rouxai' baby-leaf lettuce grown under six different lighting treatments on harvest day. Lighting treatments consisted of a photon flux density of $200 \mu \mathrm{mol} \mathrm{m} \mathrm{m}^{-2} \mathrm{~s}^{-1}$ from warm-white (WW) LEDs (control) without or with an additional $30 \mu \mathrm{mol} \mathrm{m}{ }^{-2} \mathrm{~s}^{-1}$ of UV-A (+UV30) or $50 \mu \mathrm{mol} \mathrm{m}^{-2} \mathrm{~s}^{-1}$ of WW, blue (B), green $(G)$, or red (R) light $\left(+\mathrm{WW} 50,+\mathrm{B} 50,+\mathrm{G} 50\right.$, or $+\mathrm{R} 50$, respectively) for $18 \mathrm{~h} \mathrm{~d}^{-1}$.

\begin{tabular}{ccc}
\hline Factors & F1 & F2 \\
\hline Eigenvalue & 3.278 & 2.380 \\
Variability (\%) & 40.97 & 29.75 \\
Cumulative variability (\%) & & \\
\hline & Factor Loadings & \\
\hline FW & 0.923 & 0.039 \\
DW & 0.868 & 0.084 \\
LL & 0.763 & -0.237 \\
LW & 0.924 & -0.005 \\
SPAD & 0.199 & 0.764 \\
DPPH & 0.390 & 0.463 \\
TAC & -0.140 & 0.867 \\
TPC & -0.155 & 0.875 \\
\hline Control & Factor Scores & \\
+ WW50 & -1.106 & -1.773 \\
+ UV30 & 0.237 & -0.595 \\
+B50 & 0.029 & -0.461 \\
+G50 & -1.110 & 2.974 \\
+R50 & 1.559 & 0.229 \\
\hline
\end{tabular}

FW—shoot fresh weight; DW—shoot dry weight; LL—leaf length; LW—leaf width; SPAD—relative chlorophyll concentration (index); DPPH-2.2-Diphenyl-1-picrylhydrazyl free radical scavenging activity; TAC-total anthocyanin content; TPC - total phenolic content.

To evaluate the associations between biometric measurements and lighting treatments, the PCA biplot was analyzed according to F1 and F2 factor loadings and scores. The PCA indicates that shoot FW and DW were most closely associated with the +G50 treatment. That treatment was also associated with SPAD index and antiradical activity based on DPPH measurements. Leaf length and width of baby-leaf lettuce were associated with the $+\mathrm{UV} 30$ and $+\mathrm{R} 50$ treatments, as well as $+\mathrm{WW} 50$. The TPC and TAC were associated with $+\mathrm{B} 50$. In general, the PCA biplot showed a distinct effect of +G50 from the control on growth, morphological, and biochemical parameters of baby leaf lettuce. Additionally, lighting treatments of $+\mathrm{WW} 50$, +UV30, and + R50 showed distinct effects in comparison to the control along with $\mathrm{F} 1$, and the treatments $+\mathrm{B} 50$ and +G50 differed from the control treatment along with F2. The vectors of the PCA biplot showed a significant positive correlation between shoot FW and DW $(r=0.821)$, shoot FW and leaf width $(r=0.839)$, and shoot DW and leaf width $(r=0.710)$ (Table S3). For biochemical compounds, there 
was a strong correlation between SPAD index and TAC $(r=0.601)$ and between TAC and TPC ( $r=0.699)$. DPPH measurements in lettuce did not strongly correlate with any of the biochemical parameters.

Biplot (axes F1 and F2: $70.72 \%$ )

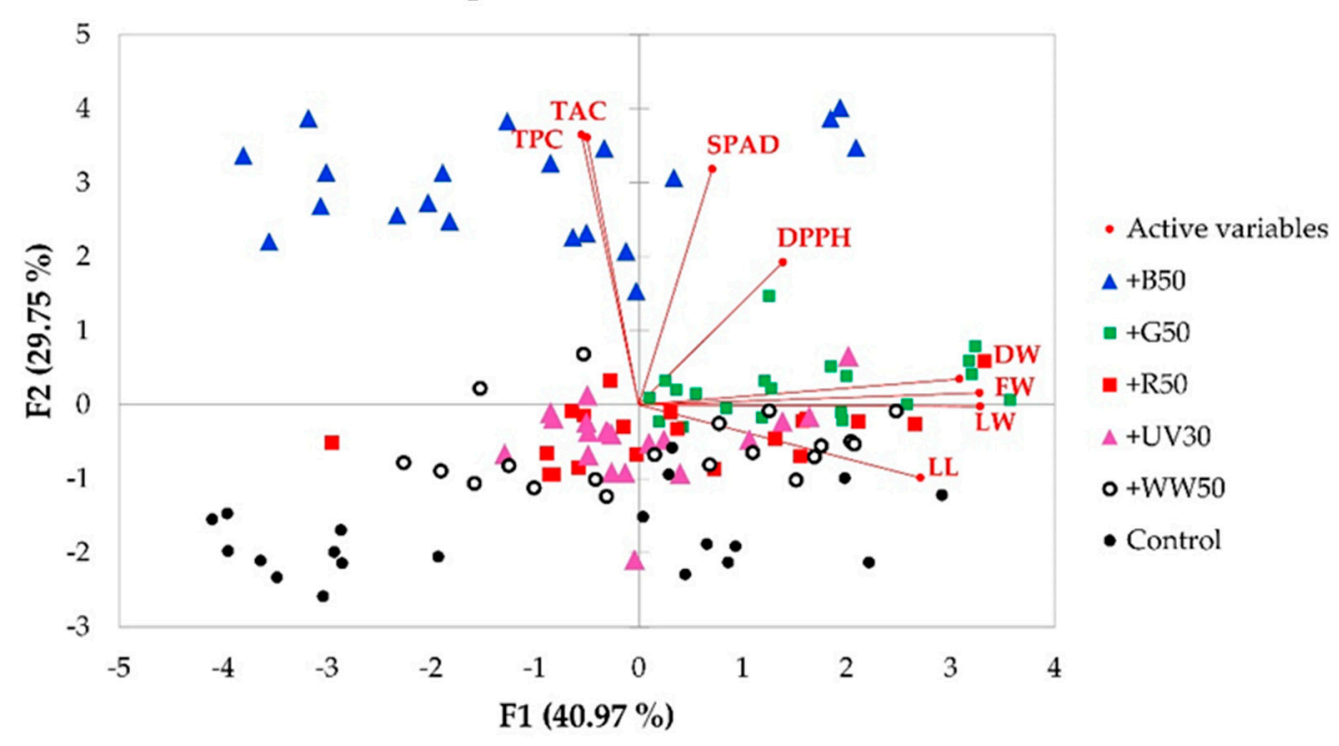

Figure 3. A principal component analysis biplot, indicating distinct effects of lighting treatments on 'Rouxai' baby-leaf lettuce and correlations between growth, morphological, and biochemical measurements. LL—leaf length; LW—leaf width; FW—fresh weight; DW—dry weight; DPPH-2.2-Diphenyl-1-picrylhydrazyl free radical scavenging activity; TPC—-total phenolic content; TAC—-total anthocyanin content. See Table S2 for the description of treatments.

\section{Discussion}

Plants have developed sophisticated ways to detect, adapt, and survive in a changing light environment. Plants interpret the detailed information from different wavelengths through the action of unique photoreceptors that are categorized into five main classes. Phytochromes primarily perceive R/FR light (600-750 nm); cryptochromes, phototropins, and F-box containing flavin binding proteins (e.g., ZEITLUPE, FKF1/LKP2) primarily respond to B and UV-A light (315-500 nm); and UVR8 is a UV-B $(280-315 \mathrm{~nm})$ photoreceptor $[17,18]$. These photoreceptors are directly involved in light perception and modulation of morphogenesis and plant biomass. They also regulate the accumulation of specialized metabolites, many of which have applications in the food or pharmaceutical industries [19].

Our experimental results demonstrate generally similar growth and leaf morphological responses of 'Rouxai' baby-leaf lettuce to each supplemental waveband of LED lighting. However, the addition of G light increased FW and DW, as well as leaf width compared to the control treatment. Although $\mathrm{R}$ and $\mathrm{B}$ light drive $\mathrm{CO}_{2}$ fixation primarily in the upper leaf layers, $\mathrm{G}$ light can better penetrate leaves and increase $\mathrm{CO}_{2}$ fixation in the lower leaf cells, leading to greater biomass accumulation [20-23]. Our results are in agreement with several other studies; for example, R + B LEDs supplemented with $24 \%$ of G light from fluorescent lamps (delivering a total PFD of $\approx 150 \mu \mathrm{mol} \mathrm{m} \mathrm{m}^{-2} \mathrm{~s}^{-1}$ ) increased shoot FW and DW of 'Waldmann's Green' lettuce compared to only R + B LEDs and cool-white or G fluorescent light at the same PFD [24]. In another study, the effects of G light on growth and morphological indices of red-leaf lettuce 'Banchu Red Fire' depended on how G light was delivered [25]. At a PFD of $300 \mu \mathrm{mol} \mathrm{m}{ }^{-2} \mathrm{~s}^{-1}$, the growth of lettuce 'Banchu Red Fire' was greater when delivered by G LEDs with a peak $=510 \mathrm{~nm}$ than fluorescent fixtures. In red romaine lettuce 'Outredgeous', early growth was more vigorous under $W$ with supplemental $\mathrm{G}$ light, leading to significantly higher FW than the W-light control $14 \mathrm{~d}$ after sowing [26]. In contrast, biomass accumulation of 'Green Oak Leaf' lettuce shoots was similar among W 
and $W+G$ lighting treatments at a comparatively low PPF of $135 \mu \mathrm{mol} \mathrm{m}{ }^{-2} \mathrm{~s}^{-1}$. [27]. A more recent study indicated that the inclusion of $G$ light did not affect shoot DW at a B PFD of 0 or $20 \mu \mathrm{mol} \mathrm{m} \mathrm{m}^{-2} \mathrm{~s}^{-1}$, but decreased it when the B PFD was 60 or $100 \mu \mathrm{mol} \mathrm{m} \mathrm{m}^{-2} \mathrm{~s}^{-1}$ [11]. However, the partial substitution of $R$ light in a B + R light background (at PFDs of 20 and $160 \mu \mathrm{mol} \mathrm{m} \mathrm{m}^{-2} \mathrm{~s}^{-1}$, respectively) with $60 \mu \mathrm{mol} \mathrm{m}^{-2} \mathrm{~s}^{-1}$ of $\mathrm{G}$ light did not influence shoot DW of lettuce 'Rouxai' grown for $11 \mathrm{~d}$. Conversely, at day 25 , substituting $60 \mu \mathrm{mol} \mathrm{m}^{-2} \mathrm{~s}^{-1}$ of G light for R decreased shoot FW and DW by $19 \%$ [28]. In another study, there were no significant growth differences in 'Red Cos' baby-leaf lettuce when grown under R + B + FR LEDs and $30 \mu \mathrm{mol} \mathrm{m} \mathrm{m}^{-2} \mathrm{~s}^{-1}$ of $\mathrm{R}$ light was substituted by $30 \mu \mathrm{mol} \mathrm{m}^{-2} \mathrm{~s}^{-1}$ of $\mathrm{G}$ light (peak $=510 \mathrm{~nm}$ ) to [12]. These conflicting reports indicate inconsistent effects of $\mathrm{G}$ light on lettuce growth, which could be because of response differences among lettuce varieties, or other factors such as effects of other wavebands (e.g., B light), different total PFDs, plant densities, and plant maturities at measurement.

Chlorophylls are green pigments in plants that are located in chloroplasts and drive photosynthesis by absorbing light and converting it into chemical energy [29]. Recently, the general phenomenon of chlorophyll hormesis among plant species and stress-inducing agents was confirmed. Hormesis is a phenomenon by which a stressor stimulates a cellular stress response, including metabolite production to help organisms establish adaptive responses. It has been suggested that chlorophyll biosynthesis in response to stress is biphasic, with the capacity to equip plants with stress-coping mechanisms by increasing chlorophyll concentrations above homeostatic levels [30]. Chlorophyll stimulation by lowdose stress occurs in tandem with enhanced growth and productivity as well as enhanced photosynthesis. Our results indicated that $+\mathrm{UV} 30,+\mathrm{G} 50$, and $+\mathrm{B} 50$ treatments increased relative chlorophyll content (SPAD index) in 'Rouxai' baby-leaf lettuce. Although UV-A light can damage the photosynthetic apparatus [31,32], recent studies of maximum quantum yield of photosystem II (PSII) photochemistry of dark- and light-adapted plants, and non-photochemical fluorescence quenching, showed photo-inhibition under supplemental UV-A (peak $=367 \mathrm{~nm}$ ) to B (peak $=447 \mathrm{~nm}$ ) and R (peak $=665 \mathrm{~nm}$ ) LEDs, whereas the photosynthetic response under B + R LEDs with or without additional UV-A (peaks = $387 \mathrm{~nm}$ and $402 \mathrm{~nm}$ ) light did not damage PSII [33]. In agreement, 'Klee' lettuce grown under additional UV-A (peak $=365 \mathrm{~nm}$ ) at a PFD of 10, 20, and $30 \mu \mathrm{mol} \mathrm{m}^{-2} \mathrm{~s}^{-1}$ had similar leaf photosynthetic rates as those grown under B + R + FR light at a PFD of $237 \mu \mathrm{mol} \mathrm{m} \mathrm{m}^{-2} \mathrm{~s}^{-1}$ [34]. In another study, chlorophyll content in 'Yanzhi' and 'Red Butter' lettuce treated with $10 \mu \mathrm{mol} \mathrm{m} \mathrm{m}^{-2} \mathrm{~s}^{-1}$ of supplemental UV-A (peak $=380 \mathrm{~nm}$ ) to $\mathrm{R}($ peak $=660 \pm 10 \mathrm{~nm})$ and W (peak $=440 \mathrm{~nm}$ ) LEDs at a ratio of 2:3 was remarkably higher than under $\mathrm{R}+\mathrm{W}, \mathrm{R}+\mathrm{W}+\mathrm{FR}$, or R + W + UV-A + FR LEDs [35]. Similarly, supplemental UV-A light (peaks = $366 \mathrm{~nm}$, $390 \mathrm{~nm}$, and $402 \mathrm{~nm}$ ) increased the chlorophyll index of red pak choi (Brassica rapa var. chinensis) 'Rubi $\mathrm{F}_{1}$ ' at a PFD of $6 \mu \mathrm{mol} \mathrm{m} \mathrm{m}^{-2} \mathrm{~s}^{-1}$ [36].

Blue light generally increases the formation of chlorophyll (Chl) a, resulting in a relatively high $\mathrm{Chl}$ a:b ratio [37]. B light increases gene expression of magnesium chelatase (MGCH) H subunit, glutamyl-tRNA reductase (GluTR), and ferrochelatase (FECH), which promotes chlorophyll synthesis [38,39]. B light also induces chlorophyll biosynthesis via the cryptochrome family of photoreceptors. Cryptochromes 1 and 2 have been both shown to affect gene expression of HEMA1 (glutamyl-tRNA reductase 1) and CHLH (magnesiumchelatase subunit) in the chlorophyll biosynthesis pathway in Arabidopsis thaliana [40]. In addition to our results, several studies with leafy green vegetables showed the promotive effect of B light on increased chlorophyll content. In 'Green Oak Leaf' lettuce, Chl a and Chl b content were both about $49 \%$ higher in plants grown under $\mathrm{W}+\mathrm{B}$ light compared to those grown under W light alone (total PFD $135 \mu \mathrm{mol} \mathrm{m}^{-2} \mathrm{~s}^{-1}$ ) [27]. In 'Kinshun' green cabbage (Brassica olearacea var. capitata) seedlings, $50 \mu \mathrm{mol} \mathrm{m}^{-2} \mathrm{~s}^{-1}$ of monochromatic B light (peak $=470 \mathrm{~nm}$ ) provided for $30 \mathrm{~d}$ increased the chlorophyll content [41]. In Chinese cabbage (Brassica campestris), B LEDs (peak $=460 \mathrm{~nm}$ ) alone and in combination with R LEDs (peak $=660 \mathrm{~nm}$ ) at a total PFD of $80 \mu \mathrm{mol} \mathrm{m} \mathrm{m}^{-2} \mathrm{~s}^{-1}$ also increased chlorophyll content [42]. 
The metabolic profile of fresh vegetables describes their nutritional quality and indicates their potential impact on human health [43]. Phenolic compounds such as flavonoids, including flavonols and anthocyanins, have greater antioxidant activity than vitamin $\mathrm{C}$ and tocopherols [44]. Phenolic compounds also play an important role as a defense mechanism against plant stresses. For example, flavonoids are the strongest singlet oxygen and hydrogen peroxide scavengers and are therefore capable of preventing photoinhibition caused by photosynthetic or UV light [45]. Phenolic acids are the main phenols in green vegetables, while anthocyanins are more common in darker-colored vegetables such as red-leaf lettuce varieties [46]. In the present study, we measured significantly higher TPC and TAC in 'Rouxai' baby-leaf lettuce cultivated under +B50 compared to the control treatment. B light-induced phenolic synthesis in leafy greens has been previously reported. For example, B light (peak $=468 \mathrm{~nm}$ ) with or without $\mathrm{R}$ light (peak $=655 \mathrm{~nm}$ ) at a total PFD of $100 \mu \mathrm{mol} \mathrm{m} \mathrm{m}^{-2} \mathrm{~s}^{-1}$ increased polyphenol content as well as total antioxidant capacity in 'Banchu Red Fire' lettuce seedlings [47]. In addition, TAC in 'Outredgeous' red-leaf lettuce was significantly higher in the presence of B light (peak $=440 \mathrm{~nm}$ ). Furthermore, TPC was over twice as high in plants grown in the presence of B light at a PFD of $30 \mu \mathrm{mol} \mathrm{m} \mathrm{m}^{-2} \mathrm{~s}^{-1}$ than in plants grown under $\mathrm{R}$ (peak $=640 \mathrm{~nm}$ ) LEDs alone (total PFD $300 \mu \mathrm{mol} \mathrm{m}{ }^{-2} \mathrm{~s}^{-1}$ ) [48]. Finally, B (peak = $\left.476 \mathrm{~nm}\right)$ LEDs (PFD $130 \mu \mathrm{mol} \mathrm{m}^{-2} \mathrm{~s}^{-1}$ ) supplemented to fluorescent lamps (total PFD $\approx 300 \mu \mathrm{mol} \mathrm{m}^{-2} \mathrm{~s}^{-1}$ ) increased TAC in 'Red Cross' lettuce compared to those grown under only fluorescent lighting [10].

Antioxidant activity is related to concentrations of secondary metabolites that have antioxidant potential, such as phenolic compounds, including anthocyanins. Although our results demonstrate that $B$ light was the most effective at increasing concentrations of compounds that have antioxidant properties, the highest antiradical activity, according to the DPPH free radical scavenging activity assay, was measured in lettuce grown under the +G50 treatment. This result is consistent with a study with 'De Lier' butterhead lettuce, in which G light (peak = $530 \mathrm{~nm})$ combined with R (peak $=660 \mathrm{~nm})$ and B (peak $=460 \mathrm{~nm})$ light at a total PFD of $200 \mu \mathrm{mol} \mathrm{m} \mathrm{m}^{-2} \mathrm{~s}^{-1}$ increased free radical scavenging activity [49]. Similarly, in wheat (Triticum aestivum) and lentil (Lens esculentum), the addition of G light $($ peak $=510 \mathrm{~nm})$ at a PFD of $15 \mu \mathrm{mol} \mathrm{m} \mathrm{m}^{-2} \mathrm{~s}^{-1}$ to $\mathrm{B}($ peak $=455 \mathrm{~nm}), \mathrm{R}($ peaks $=638$ and $669 \mathrm{~nm}$ ), and FR (peak = $731 \mathrm{~nm}$ ) light at a total PFD of $200 \mu \mathrm{mol} \mathrm{m} \mathrm{m}^{-2} \mathrm{~s}^{-1}$ increased DPPH free radical scavenging activity [50].

Factors that affect the postharvest quality of leafy greens are very broad. In general, postharvest techniques aim to prevent visual, textural, and nutritional deterioration of food that occurs rapidly after harvest [51]. Our results suggest that even though supplemental B light increased contents of phenols, including anthocyanins, and DPPH free radical scavenging activity, the most at harvest, $R$ light was among the most effective at preserving secondary metabolites during post-harvest storage. Few studies have determined the effects of the photon spectrum on the nutritional quality of leafy vegetables during postharvest storage; many more have been conducted at harvest [51]. In agreement with our results, $\mathrm{R}$ light suppressed the degradation of TPC and phenolic compounds in Chinese kale sprouts (Brassica oleracea var. alboglabra 'Bailey') during postharvest storage [15]. Consequently, the antioxidant activity of sprouts was elevated by the R light treatment. The differences in phytochemicals of lettuce grown under various lighting treatments during the postharvest storage appear to be a phenomenon that is likely linked not only to the metabolite content at harvest but also to the content of other components, e.g., nutrients or water. However, more studies are needed to clarify the mechanisms to explain the changes in metabolite contents of lettuce that were not consistent among different lighting treatments.

\section{Materials and Methods}

\subsection{Chemicals}

Potassium chloride $(\mathrm{KCl} ; \mathrm{ACS}, \geq 99.0 \%)$, sodium acetate $\left(\mathrm{CH}_{3} \mathrm{COONa}\right.$; $\left.\mathrm{ACS}, \geq 99.0 \%\right)$, hydrochloric acid ( $\mathrm{HCl}$; ACS, $\geq 37.0 \%)$, methanol $(\geq 99.9 \%)$, sulfuric acid $\left(\mathrm{H}_{2} \mathrm{SO}_{4} ; \mathrm{ACS}\right.$, 
$\geq 99.5-98.0 \%)$, Folin \& Ciocalteu's phenol reagent (F-C reagent), sodium carbonate $\left(\mathrm{Na}_{2} \mathrm{CO}_{3}\right.$; $\geq 99.0 \%$ ), gallic acid (GA; anhydrous), sodium bicarbonate $\left(\mathrm{NaHCO}_{3} ; \mathrm{ACS}, \geq 99.7 \%\right)$ were purchased from Sigma-Aldrich (Merck KGaA, Darmstadt, Germany). 2.2-Diphenyl-1picrylhydrazyl (DPPH reagent; 95\%, Alfa Aesar, Haverhill, MA, USA) was purchased from Thermo Fisher Scientific Inc. (Waltham, MA, USA).

\subsection{Plant Material and Growth Conditions}

Experiments were performed in the Controlled-Environment Lighting Laboratory at Michigan State University, East Lansing, MI, USA. On 27 July 2019 (Rep. 1) and 10 September 2019 (Rep. 2), seeds of red oakleaf lettuce 'Rouxai' (Lactuca sativa) (Johnny's Selected Seeds, Winslow, ME, USA) were sown into 200-cell $(2.5 \mathrm{~cm} \times 2.5 \mathrm{~cm}$ ) Rockwool cubes (AO 25/40 Starter Plugs; Grodan, Milton, ON, Canada), pre-soaked in deionized water with an adjusted $\mathrm{pH}$ of $4.4-4.5$ using diluted (1:31) 95-98\% sulfuric acid (J.Y. Baker, Inc., Phillipsburg, NJ, USA). Seeded cubes were placed in plastic trays and covered with transparent humidity domes, which were removed $4 \mathrm{~d}$ after seed sow. The air temperature was controlled at a constant $22{ }^{\circ} \mathrm{C}$ by a ventilation and air-conditioning unit (HBH030A3C20CRS; Heat Controller, LLC., Jackson, MI, USA) that was controlled by a wireless thermostat controller (Honeywell International, Inc., Morris Plains, NJ, USA) A total PFD of $180 \mu \mathrm{mol} \mathrm{m}{ }^{-2} \mathrm{~s}^{-1}$ from WW (peak $=639 \mathrm{~nm}$, correlated color temperature $=2700 \mathrm{~K})$ LEDs $($ PHYTOFY RL, OSRAM, Beverley, MA, USA) was delivered for $18 \mathrm{~h} \mathrm{~d}^{-1}$. Seedlings were watered with a water-soluble fertilizer (Jack's Nutrients FeEd 12-4-16 (N-P-K); JR Peters, Inc. Allentown, PA, USA) and magnesium sulfate (Pennington Epsom salt, Madison, GA, USA) to supply the following nutrients (in mg L $\left.{ }^{-1}\right): 125 \mathrm{~N}\left(117 \mathrm{NO}_{3} ; 8 \mathrm{NH}_{4}\right), 42 \mathrm{P}, 167 \mathrm{~K}, 73 \mathrm{Ca}, 47 \mathrm{Mg}, 34 \mathrm{~S}$, $0.21 \mathrm{~B}, 0.21 \mathrm{Cu}, 1.6 \mathrm{Fe}, 0.5 \mathrm{Mn}, 0.01 \mathrm{Mo}$, and $0.36 \mathrm{Zn}$. The $\mathrm{pH}$ and the electrical conductivity (EC) of the nutrient solution were measured daily using a portable meter (GroLine HI9814, Hanna Instruments, Woonsocket, RI, USA), and was adjusted using $\mathrm{H}_{2} \mathrm{SO}_{4}$ or $\mathrm{NaHCO}_{3}$ to maintain a $\mathrm{pH}$ of 5.6 , and the $\mathrm{EC}$ of $1.2 \mathrm{mS} \mathrm{cm}^{-1}$.

\subsection{Production Culture and Environment}

For each treatment, 30 lettuce seedlings were transplanted into 36-cell polystyrene rafts $(61 \times 122 \times 2.5 \mathrm{~cm}$; Beaver Plastics; Acheson, AB, Canada) and placed on floating beds (Active Aqua; New Hudson, MI, USA) in a deep-flow hydroponic system with three vertically stacked layers (Indoor Harvest, Houston, TX, USA) on 9 August 2019 (Rep. 1) and 21 September 2019 (Rep. 2). Plants were grown at an air temperature of $22{ }^{\circ} \mathrm{C}$ (controlled as described previously) with ambient $\mathrm{CO}_{2}$ and under an $18 \mathrm{~h} \mathrm{~d}^{-1}$ photoperiod (0400-2200 HR). Each hydroponic system contained a nutrient solution composed of deionized water and the same fertilizer as described previously but elevated by $20 \%$ (e.g., $\left.150 \mathrm{mg} \mathrm{L}^{-1} \mathrm{~N}\right)$, which was recirculated and oxygenated with an air stone $(20.3 \times 2.5 \mathrm{~cm}$; Active Aqua AS8RD; Hydrofarm, Petaluma, CA, USA) and a 60-W air pump (Active Aqua AAPA70L; Hydrofarm). The $\mathrm{pH}\left(5.6 \pm 0.4\right.$ standard deviations) and EC $\left(1.7 \pm 0.3 \mathrm{mS} \mathrm{cm}^{-1}\right)$ of the nutrient solution tanks were measured daily as described previously and adjusted using $\mathrm{H}_{2} \mathrm{SO}_{4}$ or $\mathrm{NaHCO}_{3}$. Thermocouples (0.13-mm type E; Omega Engineering, Inc., Stamford, CT, USA), infrared temperature sensors (OS36-01-K-80 F; Omega Engineering, Inc.), light quantum sensors (LI-190R; LI-COR, Inc., Lincoln, NE, USA), $\mathrm{CO}_{2}$ sensors (GMD20; Vaisala, Inc., Louisville, CO, USA), and relative humidity and temperature probes (HMP110; Vaisala, Inc.) were used to monitor corresponding environmental parameters. One or two sensors of each type were positioned in representative locations of the growth room.

\subsection{Lighting Treatments}

After transplant, plants were grown under six different lighting treatments delivered by UV-A $($ peak $=385 \mathrm{~nm})$, blue $(\mathrm{B}$; peak $=449 \mathrm{~nm})$, green $(\mathrm{G}$; peak $=526 \mathrm{~nm})$, red $(\mathrm{R}$; peak $=664 \mathrm{~nm}$ ), and WW (peak $=639 \mathrm{~nm})$ LEDs, each of which was independently controlled and housed in the same fixture (PHYTOFY RL, OSRAM, Beverley, MA, USA) 
(Table 2). The PFD of each color channel was controlled at a $1 \mu \mathrm{mol} \mathrm{m}^{-2} \mathrm{~s}^{-1}$ increment using proprietary software (Spartan Control Software; OSRAM, Beverley, MA, USA). Three LED fixtures $(67.3 \times 29.8 \times 4.3 \mathrm{~cm}$ each) were positioned $47 \mathrm{~cm}$ above each raft and spaced on 41-cm centers to achieve reasonably good PFD uniformity. Lighting treatments consisted of $200 \mu \mathrm{mol} \mathrm{m} \mathrm{m}^{-2} \mathrm{~s}^{-1}$ of WW light (control) without or with an additional $30 \mu \mathrm{mol} \mathrm{m}^{-2} \mathrm{~s}^{-1}$ of UV-A (+UV30) or $50 \mu \mathrm{mol} \mathrm{m}^{-2} \mathrm{~s}^{-1}$ of WW, B, G, or R light (+WW50, +B50, +G50, or +R50, respectively) for $18 \mathrm{~h} \mathrm{~d}^{-1}$ (Table 2). The photon distributions of all lighting treatments were measured using a portable spectroradiometer (PS200; Apogee Instruments, Inc., Logan, UT, USA).

Table 2. LED types and photon flux densities (PFD) were used to deliver six lighting treatments used in experiments.

\begin{tabular}{cccccccc}
\hline \multirow{2}{*}{$\begin{array}{c}\text { Lighting } \\
\text { Treatments }\end{array}$} & $\begin{array}{c}\text { Warm-White } \\
\text { (WW) }\end{array}$ & $\begin{array}{c}\text { UV-A } \\
\text { (UV) }\end{array}$ & $\begin{array}{c}\text { Blue } \\
\text { (B) }\end{array}$ & $\begin{array}{c}\text { Green } \\
\text { (G) }\end{array}$ & $\begin{array}{c}\text { Red } \\
\text { (R) }\end{array}$ & Total & DTPFDI \\
\hline Control & 200 & & & & & 200 & 12.9 \\
+ +WW50 & 250 & & & & 250 & 16.2 \\
+ +UV30 & 200 & 30 & & & 230 & 14.9 \\
+ +B50 & 200 & & 50 & & & 250 & 16.2 \\
+G50 & 200 & & & 50 & & 250 & 16.2 \\
+ +R50 & 200 & & & & 50 & 250 & 16.2 \\
\hline
\end{tabular}

DTPFI-daily total photon flux density integral, $\mathrm{mol} \mathrm{m}^{-2} \mathrm{~d}^{-1}$.

\subsection{Postharvest Storage Conditions}

For the postharvest portion of this experiment, five fresh-cut baby-leaf lettuce plants from each lighting treatment were harvested $17 \mathrm{~d}$ after seed sow and stored in clear $23 \times 24 \times 8 \mathrm{~cm}$ clamshell polyethylene terephthalate (PET) containers in darkness at $5{ }^{\circ} \mathrm{C}$ and $70 \%$ relative humidity for $1,3,5$, and $7 \mathrm{~d}$.

\subsection{Biometric Measurements and Water Content Determination}

After $17 \mathrm{~d}$ from seed sow, destructive measurements were conducted on ten baby-leaf lettuce plants from each lighting treatment and replication. Each plant was cut from the Rockwool cube and shoot FW (g) and DW (g) were measured using an analytical balance (AG245; Mettler Toledo, Columbus, OH, USA). Leaf length $(\mathrm{cm})$ and width $(\mathrm{cm})$ of the third fully expanded leaf, and leaf number (when $>2 \mathrm{~cm}$ ) were measured. Shoots were dried in an oven (Blue M, Blue Island, IL, USA) at $60{ }^{\circ} \mathrm{C}$ for $4 \mathrm{~d}$ before DW measurements. Water content was calculated as the fraction of the difference between shoot FW and DW in FW and used for the re-calculation of biochemical compound contents in the DW of plants.

\subsection{Non-Destructive Estimation of Chlorophyll Content}

The relative chlorophyll content (SPAD) was evaluated using an MC-100 m (Apogee Instruments, Inc, Logan, UT, USA) based on ratio measurements of light transmittance from red and near-infrared wavelengths. Three measurements were made on the third fully expanded leaf of ten plants from each lighting treatment, from two replicates of the experiment, to calculate an average SPAD value. The results are presented as means of SPAD indexes.

\subsection{Biochemical Analysis}

For each lighting treatment within a replication, conjugated biological samples of the third leaf from three randomly selected plants were used for biochemical analysis. Three analytical replicates were performed for each biochemical measurement. Fresh plant tissue was immediately frozen with $10 \mathrm{~mL}$ liquid nitrogen $\left(\mathrm{N}_{2}\right)$ and stored in an ultra-low freezer at $-80^{\circ} \mathrm{C}$ until analysis. 


\subsubsection{Quantification of Total Phenolic Content}

The total phenolic content (TPC) of lettuce was determined spectrophotometrically [52] with slight modifications. Frozen fresh plant tissue $(500 \mathrm{mg})$ was homogenized in a ceramic mortar with $5 \mathrm{~mL}$ of $80 \%$ ice-cold methanol and transferred to a $15 \mathrm{~mL}$ polypropylene conical centrifuge tube (Falcon, Thermo Fisher Scientific Inc.). The extract was incubated at $4{ }^{\circ} \mathrm{C}$ for $24 \mathrm{~h}$. Samples were centrifuged (Heraeus Megafuge, Thermo Fisher Scientific Inc.) at a relative centrifugal force of $4000 \times g$ for $5 \mathrm{~min}$ at room temperature, and the supernatant was filtered through a $70 \mathrm{~mm}$ qualitative filter paper (Whatman Qualitative Filter Paper Grade 1, Thermo Fisher Scientific Inc.). $100 \mu \mathrm{L}$ of the filtrate was diluted with $200 \mu \mathrm{L}$ of $10 \%$ ( vol/vol) F-C reagent and vortexed thoroughly. Then, $800 \mu \mathrm{L}$ of $700 \mathrm{mM}$ of $\mathrm{Na}_{2} \mathrm{CO}_{3}$ was added. The prepared analytical samples were covered and left to stand for $20 \mathrm{~min}$. The absorbance of the samples was measured using a spectrophotometer (BioSpec-mini; Shimadzu, Japan) at $765 \mathrm{~nm}$. The TPC in fresh plant tissues was calculated using a standard curve of GA $\left(R^{2}>0.95\right)$. Data are presented as the mean of three analytical measurements of TPC (in $\mathrm{mg} \mathrm{g}^{-1}$ ) on a dry basis of the plant.

\subsubsection{Quantification of Total Monomeric Anthocyanin Pigment Content}

Total anthocyanin content (TAC) was determined by the $\mathrm{pH}$ differential method (AOAC Official Method 2005.2) [53] with slight modifications. We used the molar extinction coefficient of $34,300 \mathrm{~L} \mathrm{~cm}^{-1} \mathrm{M}^{-1}$ by using molecular weight $449.2 \mathrm{~g} \mathrm{M}^{-1}$ for cyanidin-3glucoside for measurements of TAC in frozen fresh plant powder $(300 \mathrm{mg})$ prepared with $1 \% \mathrm{HCl}$ in methanol [54]. The method is based on the anthocyanin structural transformation that occurs with a change in $\mathrm{pH}$ (colored at $\mathrm{pH} 1.0$ and colorless at $\mathrm{pH}$ 4.5). The prepared samples were incubated at $4{ }^{\circ} \mathrm{C}$ for $48 \mathrm{~h}$. Then, samples were centrifuged as previously described, and the supernatant was filtered through filter paper as previously described. Two separate analytical samples were prepared to measure TAC in the plant extract. $400 \mu \mathrm{L}$ of the extract was mixed with $2 \mathrm{~mL}$ of $0.025 \mathrm{M} \mathrm{KCl}$ and $2 \mathrm{~mL}$ of $0.4 \mathrm{M} \mathrm{CH}_{3} \mathrm{COONa}$, and after $20 \mathrm{~min}$, the absorbance was measured at $530 \mathrm{~nm}$ and $700 \mathrm{~nm}$ using the same spectrophotometer. The dilution factor was 6. Data are presented as a mean of three analytical TAC measurements (in $\mathrm{mg} \mathrm{g}^{-1}$ ) on a dry basis of the plant.

4.8.3. Evaluation of Antiradical Activity by 2.2-Diphenyl-1-Picrylhydrazyl Free Radical (DPPH) Scavenging Activity Method

The antiradical activity was evaluated according to the spectrophotometric DPPH scavenging activity method $[55,56]$ with modifications. $100 \mu \mathrm{L}$ of $80 \%$ methanol extracts used for the TPC assay were diluted with $1 \mathrm{~mL}$ of $60 \mu \mathrm{M}$ DPPH solution. The absorbance was measured after 16 min using the same spectrophotometer at $515 \mathrm{~nm}$. The ability of plant extract to scavenge DPPH free radicals was calculated using the DPPH solution as a blank. Data are presented as the mean of three analytical samples to scavenge DPPH free radicals (in $\mu \mathrm{mol} \mathrm{g}^{-1}$ ) on a dry basis of the plant.

\subsection{Statistical Analysis}

The experiment was arranged as a randomized complete block design with two replications (blocks) in time. Statistical analysis was conducted using $R$ statistical analysis software (version 3.5.1; R Foundation for Statistical Computing, Vienna, Austria). Analysis of variance (ANOVA) and Tukey's honestly significant difference test $(\alpha=0.05)$ was performed using the R packages 'dplyr' [57] and 'agricolae' [58] and compared with the control treatment. For the ANOVA of biochemical compounds of plants under storage conditions, new samples were taken each day of investigation $(1,3,5$, and $7 \mathrm{~d}$ after the harvest), and compared to samples under control (WW) on the same day. Finally, linear regression analysis was performed on the biochemical compound concentrations during storage using SigmaPlot 14.0 (Systat Software, Inc, San Jose, CA, USA). 


\subsection{Principal Component Analysis}

Principal component analysis (PCA) was performed using Microsoft ${ }^{\circledR}$ Excel ${ }^{\circledR}$ for 'Microsoft 365' and Addinsoft XLSTAT 2020 statistical and data analysis solution (Long Island, NY, USA). The PCA was performed at a 95\% significance level. The results presented in the PCA biplot indicate distinct effects of lighting treatments on plant growth and morphology parameters or contents of biochemical compounds, and Pearson's correlation matrix summarized relationships between biometric measurements or investigated biochemical compounds in baby leaf lettuces under the lighting treatments.

\section{Conclusions}

The addition of light from UV-A, B, G, R, or WW LEDs differently regulated 'Rouxai' baby-leaf growth and leaf morphology. However, the addition of $\mathrm{G}$ light led to the greatest plant growth and leaf width as well as chlorophyll content in lettuce leaves. In addition, plants grown under UV-A, and especially B light, had significantly higher relative chlorophyll content. Supplemental UV-A and B light promoted the accumulation of secondary metabolites in baby-leaf lettuce, but significant changes in TPC and TAC were in plants grown under supplemental B light. However, the highest antioxidant activity (according to DPPH free radical scavenging activity) was in lettuce grown under supplemental G light. During postharvest storage, the TPC and DPPH free radical activity decreased, and the TAC degradation was lower. Despite that, supplemental B light increased the contents of secondary metabolites at harvest, while $\mathrm{R}$ light was among the most effective at preserving phytochemicals during short-term postharvest storage.

Supplementary Materials: The following are available online at https:/ /www.mdpi.com/2223-77 47/10/3/549/s1, Table S1: Total phenolic content, total anthocyanin content, and antiradical activity of 'Rouxai' baby-leaf lettuce plants under different lighting treatments on harvest day and during postharvest storage, Table S2: Coefficients for linear regression equations presented in Figure 3, in the form of $y=y 0+a x$, and their correlation coefficients $\left(R^{2}\right)$, Table S3: Correlation matrix (Pearson) between biometric and biochemical measurements of baby leaf lettuce, Figure S1: Scree plot of biometric and biochemical measurements of baby leaf lettuce under different lighting treatments.

Author Contributions: Conceptualization, E.S.R., N.K. and V.V.-K.; methodology, E.S.R. and V.V.-K.; software, E.S.R., N.K., V.V.-K.; validation, E.S.R., N.K. and V.V.-K.; formal analysis, V.V.-K.; investigation, V.V.-K.; resources, E.S.R.; data curation, E.S.R. and V.V.-K.; writing - original draft preparation, V.V.-K.; writing-review and editing, E.S.R. and N.K.; visualization, E.S.R. and V.V.-K.; supervision, E.S.R.; project administration, E.S.R.; funding acquisition, E.S.R. All authors have read and agreed to the published version of the manuscript.

Funding: This work was supported by the Specialty Crops Research Initiative (grant no. 2019-51181-30017) and Hatch project 192266 from the USDA National Institute of Food and Agriculture; and the BalticAmerican Freedom Foundation Research Scholar Program.

Acknowledgments: The authors thank for Ryan Warner, Roberto Lopez and Sue Hammar for sharing laboratory space and instruments; Osram for lighting support and Grodan and JR Peters for material donations.

Conflicts of Interest: The authors declare no conflict of interest.

\section{References}

1. Van Iersel, M.W. Optimizing LED lighting in controlled environment agriculture. In Light Emitting Diodes for Agriculture; Springer: Berlin/Heidelberg, Germany, 2017; pp. 59-80.

2. Benke, K.; Tomkins, B. Future food-production systems: Vertical farming and controlled-environment agriculture. Sustainability 2017, 13, 13-26. [CrossRef]

3. Gupta, S.D.; Agarwal, A. Light Emitting Diodes for Agriculture; Springer: Berlin/Heidelberg, Germany, 2017.

4. $\mathrm{Xu}, \mathrm{Y}$. Nature and source of light for plant factory. In Plant Factory Using Artificial Light; Elsevier: Amsterdam, The Netherlands, 2019; pp. 47-69.

5. Mitchell, C.A.; Sheibani, F. LED advancements for plant-factory artificial lighting. In Plant Factory; Elsevier: Amsterdam, The Netherlands, 2020; pp. 167-184. 
6. Baslam, M.; Morales, F.; Garmendia, I.; Goicoechea, N. Nutritional quality of outer and inner leaves of green and red pigmented lettuces (Lactuca sativa L.) consumed as salads. Sci. Hortic. 2013, 151, 103-111. [CrossRef]

7. Kim, M.J.; Moon, Y.; Tou, J.C.; Mou, B.; Waterland, N.L. Nutritional value, bioactive compounds and health benefits of lettuce (Lactuca sativa L.). J. Food Compos. Anal. 2016, 49, 19-34. [CrossRef]

8. Bazzano, L.A.; He, J.; Ogden, L.G.; Loria, C.M.; Vupputuri, S.; Myers, L.; Whelton, P.K. Fruit and vegetable intake and risk of cardiovascular disease in us adults: The first national health and nutrition examination survey epidemiologic follow-up study. Am. J. Clin. Nutr. 2002, 76, 93-99. [CrossRef] [PubMed]

9. Hung, H.-C.; Joshipura, K.J.; Jiang, R.; Hu, F.B.; Hunter, D.; Smith-Warner, S.A.; Colditz, G.A.; Rosner, B.; Spiegelman, D.; Willett, W.C. Fruit and vegetable intake and risk of major chronic disease. J. Natl. Cancer Inst. 2004, 96, 1577-1584. [CrossRef] [PubMed]

10. Li, Q.; Kubota, C. Effects of supplemental light quality on growth and phytochemicals of baby leaf lettuce. Environ. Exp. Bot. 2009, 67, 59-64. [CrossRef]

11. Meng, Q.; Boldt, J.; Runkle, E.S. Blue radiation interacts with green radiation to influence growth and predominantly controls quality attributes of lettuce. J. Am. Soc. Hortic. Sci. 2020, 1, 1-13. [CrossRef]

12. Viršilè, A.; Brazaitytè, A.; Vaštakaitè-Kairienè, V.; Miliauskienė, J.; Jankauskienė, J.; Novičkovas, A.; Laužikè, K.; Samuolienè, G. The distinct impact of multi-color LED light on nitrate, amino acid, soluble sugar and organic acid contents in red and green leaf lettuce cultivated in controlled environment. Food Chem. 2020, 310, 125799. [CrossRef]

13. Witkowska, I.M. Factors Affecting the Postharvest Performance of Fresh-Cut Lettuce. Ph.D. Thesis, Wageningen University, Wageningen, The Netherlands, 2013.

14. Brecht, J.K. Physiology of lightly processed fruits and vegetables. HortScience 1995, 30, 18-22. [CrossRef]

15. Deng, M.; Qian, H.; Chen, L.; Sun, B.; Chang, J.; Miao, H.; Cai, C.; Wang, Q. Influence of pre-harvest red light irradiation on main phytochemicals and antioxidant activity of chinese kale sprouts. Food Chem. 2017, 222, 1-5. [CrossRef] [PubMed]

16. Nicole, C.; Mooren, J.; Pereira Terra, A.; Larsen, D.; Woltering, E.; Marcelis, L.; Verdonk, J.; Schouten, R.; Troost, F. Effects of LED lighting recipes on postharvest quality of leafy vegetables grown in a vertical farm. Acta Hortic. 2017, 1256, 481-488. [CrossRef]

17. Legris, M.; Klose, C.; Burgie, E.S.; Rojas, C.C.R.; Neme, M.; Hiltbrunner, A.; Wigge, P.A.; Schäfer, E.; Vierstra, R.D.; Casal, J.J. Phytochrome B integrates light and temperature signals in arabidopsis. Science 2016, 354, 897-900. [CrossRef]

18. Jung, J.-H.; Domijan, M.; Klose, C.; Biswas, S.; Ezer, D.; Gao, M.; Khattak, A.K.; Box, M.S.; Charoensawan, V.; Cortijo, S. Phytochromes function as thermosensors in arabidopsis. Science 2016, 354, 886-889. [CrossRef] [PubMed]

19. Paik, I.; Huq, E. Plant Photoreceptors: Multi-Functional Sensory Proteins and Their Signaling Networks; Academic Press: Cambridge, MA, USA, 2019; Volume 92, pp. 114-121.

20. McCree, K.J. The action spectrum, absorptance and quantum yield of photosynthesis in crop plants. Agric. Meteorol. 1971, 9 , 191-216. [CrossRef]

21. Sun, J.; Nishio, J.N.; Vogelmann, T.C. Green light drives $\mathrm{CO}_{2}$ fixation deep within leaves. Plant Cell Physiol. 1998, 39, 1020-1026. [CrossRef]

22. Wang, Y.; Folta, K.M. Contributions of green light to plant growth and development. Am. J. Bot. 2013, 100, 70-78. [CrossRef] [PubMed]

23. Bugbee, B. Economics of LED lighting. In Light Emitting Diodes for Agriculture; Springer: Berlin/Heidelberg, Germany, 2017; pp. 81-99.

24. Kim, H.-H.; Goins, G.D.; Wheeler, R.M.; Sager, J.C. Green-light supplementation for enhanced lettuce growth under red- and blue-light-emitting diodes. HortScience 2004, 39, 1617-1622. [CrossRef]

25. Johkan, M.; Shoji, K.; Goto, F.; Hahida, S.; Yoshihara, T. Effect of green light wavelength and intensity on photomorphogenesis and photosynthesis in lactuca sativa. Environ. Exp. Bot. 2012, 75, 128-133. [CrossRef]

26. Mickens, M.; Skoog, E.; Reese, L.; Barnwell, P.; Spencer, L.; Massa, G.; Wheeler, R. A strategic approach for investigating light recipes for 'outredgeous' red romaine lettuce using white and monochromatic LEDs. Life Sci. Space Res. 2018, 19, 53-62. [CrossRef] [PubMed]

27. Chen, X.; Xue, X.; Guo, W.; Wang, L.; Qiao, X. Growth and nutritional properties of lettuce affected by mixed irradiation of white and supplemental light provided by light-emitting diode. Sci. Hortic. 2016, 200, 111-118. [CrossRef]

28. Meng, Q.; Runkle, E.S. Growth responses of red-leaf lettuce to temporal spectral changes. Front. Plant Sci. 2020, 11, 1623. [CrossRef] [PubMed]

29. Smith, J.H.; Benitez, A. Chlorophylls: Analysis in plant materials. In Modern Methods of Plant Analysis/Moderne Methoden der Pflanzenanalyse; Springer: Berlin/Heidelberg, Germany, 1955; pp. 142-196.

30. Agathokleous, E.; Barceló, D.; Tsatsakis, A.; Calabrese, E.J. Hydrocarbon-induced hormesis: 101 years of evidence at the margin? Environ. Pollut. 2020, 265, 114846. [CrossRef]

31. Vass, I.; Turcsányi, E.; Touloupakis, E.; Ghanotakis, D.; Petrouleas, V. The mechanism of UV-A radiation-induced inhibition of photosystem II electron transport studied by EPR and chlorophyll fluorescence. Biochemistry 2002, 41, 10200-10208. [CrossRef]

32. Tyystjärvi, E. Photoinhibition of photosystem II and photodamage of the oxygen evolving manganese cluster. Coord. Chem. Rev. 2008, 252, 361-376. [CrossRef]

33. Samuolienè, G.; Viršilè, A.; Miliauskienè, J.; Haimi, P.; Laužikè, K.; Jankauskienè, J.; Novičkovas, A.; Kupčinskienė, A.; Brazaitytè, A. The photosynthetic performance of red leaf lettuce under UV-A irradiation. Agronomy 2020, 10, 761. [CrossRef] 
34. Chen, Y.; Li, T.; Yang, Q.; Zhang, Y.; Zou, J.; Bian, Z.; Wen, X. UVA radiation is beneficial for yield and quality of indoor cultivated lettuce. Front. Plant Sci. 2019, 10, 1563. [CrossRef]

35. He, R.; Zhang, Y.; Song, S.; Su, W.; Hao, Y.; Liu, H. UV-A and FR irradiation improves growth and nutritional properties of lettuce grown in an artificial light plant factory. Food Chem. 2021, 345, 128727. [CrossRef] [PubMed]

36. Brazaityte, A.; Virsile, A.; Jankauskiene, J.; Sakalauskiene, S.; Samuoliene, G.; Sirtautas, R.; Novickovas, A.; Dabasinskas, L.; Miliauskiene, J.; Vastakaite, V. Effect of supplemental UV-A irradiation in solid-state lighting on the growth and phytochemical content of microgreens. Int. Agrophys. 2015, 29, 13-22. [CrossRef]

37. Fan, X.; Zang, J.; Xu, Z.; Guo, S.; Jiao, X.; Liu, X.; Gao, Y. Effects of different light quality on growth, chlorophyll concentration and chlorophyll biosynthesis precursors of non-heading chinese cabbage (Brassica campestris L.). Acta Physiol. Plant. 2013, 35 2721-2726. [CrossRef]

38. Wang, H.; Gu, M.; Cui, J.; Shi, K.; Zhou, Y.; Yu, J. Effects of light quality on $\mathrm{CO}_{2}$ assimilation, chlorophyll-fluorescence quenching, expression of calvin cycle genes and carbohydrate accumulation in cucumis sativus. J. Photochem. Photobiol. B 2009, 96, 30-37. [CrossRef]

39. Poudel, P.R.; Kataoka, I.; Mochioka, R. Effect of red-and blue-light-emitting diodes on growth and morphogenesis of grapes. Plant Cell Tissue Organ Cult. 2008, 92, 147-153. [CrossRef]

40. McCormac, A.C.; Fischer, A.; Kumar, A.M.; Söll, D.; Terry, M.J. Regulation of HEMA1 expression by phytochrome and a plastid signal during de-etiolation in arabidopsis thaliana. Plant J. 2001, 25, 549-561. [CrossRef] [PubMed]

41. Mizuno, T.; Amaki, W.; Watanabe, H. Effects of monochromatic light irradiation by LED on the growth and anthocyanin contents in leaves of cabbage seedlings. Acta Hortic. 2011, 907, 179-184. [CrossRef]

42. Li, H.; Tang, C.; Xu, Z.; Liu, X.; Han, X. Effects of different light sources on the growth of non-heading chinese cabbage (Brassica campestris L.). J. Agric. Sci. 2012, 4, 262. [CrossRef]

43. Sytar, O.; Hemmerich, I.; Zivcak, M.; Rauh, C.; Brestic, M. Comparative analysis of bioactive phenolic compounds composition from 26 medicinal plants. Saudi J. Biol. Sci. 2018, 25, 631-641. [CrossRef] [PubMed]

44. Rice-Evans, C.; Miller, N.; Paganga, G. Antioxidant properties of phenolic compounds. Trends Plant Sci. 1997, 2, 152-159. [CrossRef]

45. Csepregi, K.; Hideg, É. Phenolic compound diversity explored in the context of photo-oxidative stress protection. Phytochem. Anal. 2018, 29, 129-136. [CrossRef]

46. Llorach, R.; Martínez-Sánchez, A.; Tomás-Barberán, F.A.; Gil, M.I.; Ferreres, F. Characterisation of polyphenols and antioxidant properties of five lettuce varieties and escarole. Food Chem. 2008, 108, 1028-1038. [CrossRef] [PubMed]

47. Johkan, M.; Shoji, K.; Goto, F.; Hashida, S.; Yoshihara, T. Blue light-emitting diode light irradiation of seedlings improves seedling quality and growth after transplanting in red leaf lettuce. HortScience 2010, 45, 1809-1814. [CrossRef]

48. Stutte, G.W.; Edney, S.; Skerritt, T. Photoregulation of bioprotectant content of red leaf lettuce with light-emitting diodes. HortScience 2009, 44, 79-82. [CrossRef]

49. Bian, Z.-H.; Cheng, R.-F.; Yang, Q.-C.; Wang, J.; Lu, C. Continuous light from red, blue, and green light-emitting diodes reduces nitrate content and enhances phytochemical concentrations and antioxidant capacity in lettuce. J. Am. Soc. Hortic. Sci. 2016, 141, 186-195. [CrossRef]

50. Samuolienè, G.; Urbonavičiūtè, A.; Brazaitytė, A.; Šabajevienè, G.; Sakalauskaitė, J.; Duchovskis, P. The impact of LED illumination on antioxidant properties of sprouted seeds. Open Life Sci. 2011, 6, 68-74. [CrossRef]

51. D'Souza, C.; Yuk, H.; Khoo, G.H.; Zhou, W. Application of light-emitting diodes in food production, postharvest preservation, and microbiological food safety. Compr. Rev. Food Sci. Food Saf. 2015, 14, 719-740. [CrossRef]

52. Ainsworth, E.A.; Gillespie, K.M. Estimation of total phenolic content and other oxidation substrates in plant tissues using folin-ciocalteu reagent. Nat. Protoc. 2007, 2, 875-877. [CrossRef] [PubMed]

53. Lee, J.; Durst, R.W.; Wrolstad, R.E. Determination of total monomeric anthocyanin pigment content of fruit juices, beverages, natural colorants, and wines by the ph differential method: Collaborative study. J. AOAC Int. 2005, 88, 1269-1278. [CrossRef] [PubMed]

54. Wrolstad, R.E.; Durst, R.W.; Giusti, M.M.; Rodriguez-Saona, L.E. Analysis of anthocyanins in nutraceuticals. In Quality Management of Nutraceuticals; American Chemical Society: Washington, DC, USA, 2002; ISBN 1947-5918.

55. Sharma, O.P.; Bhat, T.K. DPPH Antioxidant assay revisited. Food Chem. 2009, 113, 1202-1205. [CrossRef]

56. Mishra, K.; Ojha, H.; Chaudhury, N.K. Estimation of antiradical properties of antioxidants using DPPH assay: A critical review and results. Food Chem. 2012, 130, 1036-1043. [CrossRef]

57. Wickham, H.; Averick, M.; Bryan, J.; Chang, W.; McGowan, L.D.; François, R.; Grolemund, G.; Hayes, A.; Henry, L.; Hester, J. Welcome to the Tidyverse. J. Open Source Softw. 2019, 4, 1686. [CrossRef]

58. De Mendiburu, F.; de Mendiburu, M.F. Package 'Agricolae'; Version 1.3-3; R Package: Madison, WI, USA, 7 June 2020. 